\title{
Pleomorphic Liposarcoma in an Aged Rat
}

\author{
Yoshio MINATO, Hiroshi TAKADA, Hisashi YAMANAKA, Akihiro KOJIMA, Isao WADA, \\ Masakazu TAKESHITA, and Azusa OKANIWA \\ Safety Research Laboratory, Tanabe Seiyaku Co., Ltd., 16-89, Kashima 3-chome, Yodogawa, Osaka 532,Japan
}

(Received 22 August 1984/Accepted 25 December 1985)

\begin{abstract}
Histopathological observations were made on pleomorphic liposarcoma found in the omentum and mesentery of a 68 -week-old rat. The tumor consisted of two types of tumor cells; round cells that had abundant cytoplasm with a clear large nucleus and spindle-shaped, slender cells with dark oval nuclei. Some round cells contained features suggesting ongoing lipid synthesis in the dilatated cistern of the rough endoplasmic reticulum. Both types of cells had various sizes of lipid droplets with no limited membrane.-KEY WORDS: liposarcoma, rat.
\end{abstract}

Jpn. J. Vet. Sci. 48(2): 429-432, 1986

Liposarcoma occurs relatively rarely in experimental animals, and only a few cases have been reported in rats used for long-term studies. Jacobs et al. [6] found one case (abdominal cavity) out of 194 of F344 strain; Goodman et al. [4] detected 2 cases (subcutis) out of 3538 rats of the same strain, and Goodman et al. [5] reported 6 cases (integument) out of 1945 rats of the Osborn-Mendel strain. These authors, however, presented no detailed morphological description of the tumors. The present study was undertaken to characterize morphologic features of liposarcoma in rats.

A male animal of the KBL: Wistar strain, 68 weeks of age and $688 \mathrm{~g}$ in body weight, was found dead with a distended abdomen. In addition to the usual gross and histopathological examinations, an ultrastructural examination was carried out on the formalin-fixed tumor tissue.

Grossly a multinodular tumor mass was found in the omentum with numerous nodules in the mesentery (Fig. 1). The tumor showed an elastic, firm consistency, with a solid, translucent appearance and a yellowish-white cut surface. Similar nodules were found at the hilum of the spleen, and at the diaphrag- matic surface of the liver.

Microscopically, the tumor cells were mainly composed of two different types of cells; one type had abundant cytoplasm with clear large nuclei (round cell), and the others were slender in shape with dark oval to long spheroidal nuclei (spindle cell) (Fig. 2). Both types manifested abundant mitotic figures. The ratio of the two cell types varied from place to place in the tumor tissue. Some of the round cells had scanty cytoplasm with

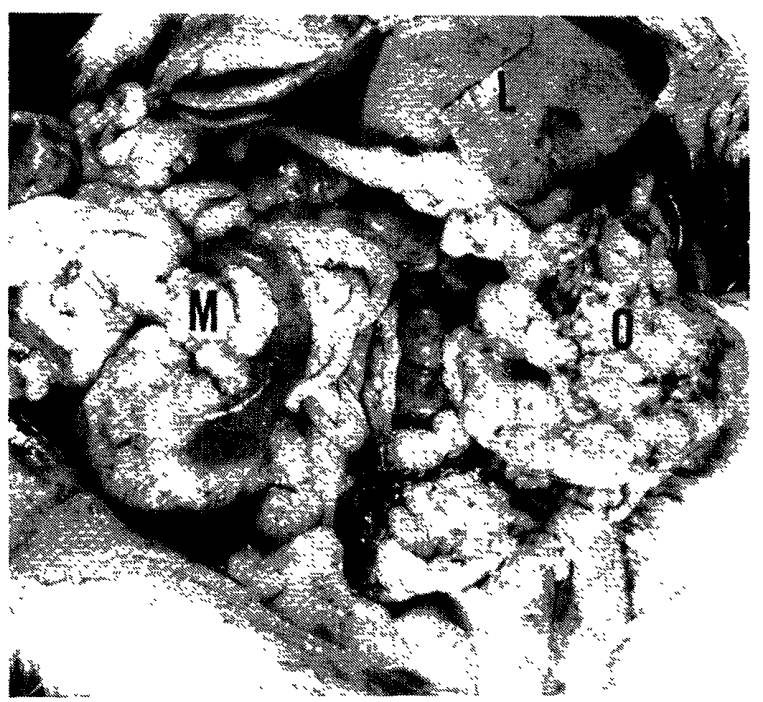

Fig. 1. Gross appearance showing multinodular mass in the omentum $(\mathrm{O})$ or numerous granules in the mesentery $(\mathrm{M})$. L: Liver 


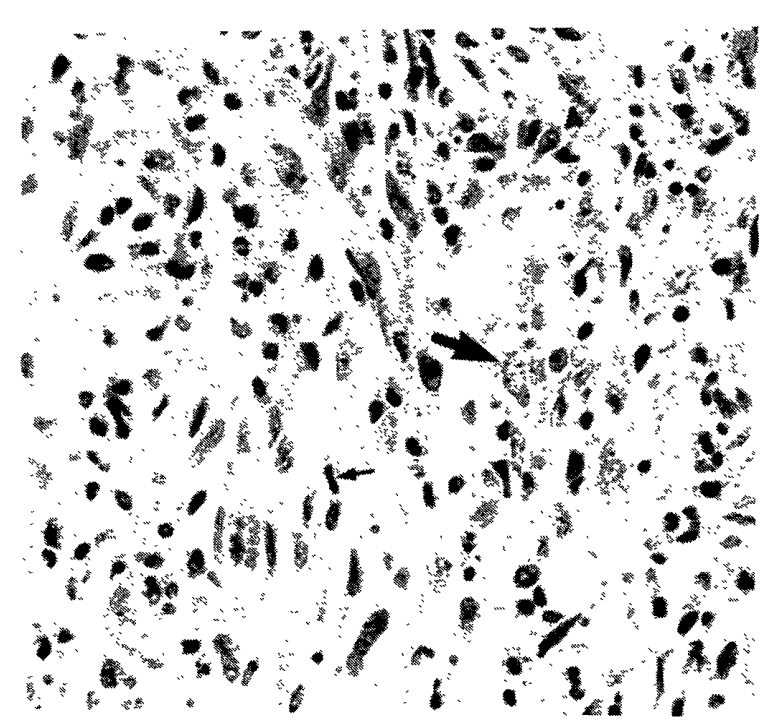

Fig. 2. Round (thick arrow) and spindle (thin arrow) tumor cells and well-differentiated typical mature fat cells (signet-ring cell) in the tumor of omentum. HE staining, $\times 250$.

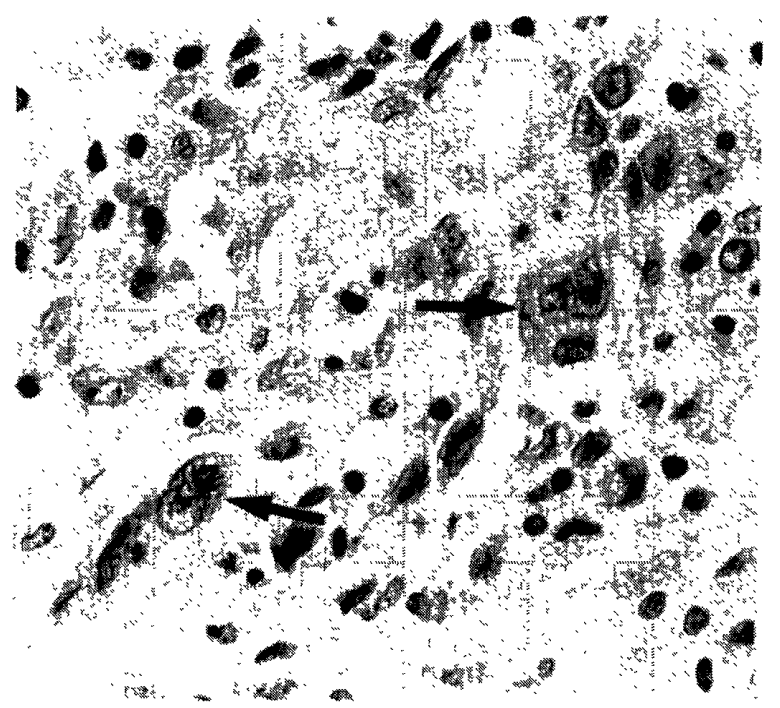

Fig. 3. Giant lipoblasts (arrows) in pleomorphic area. HE staining, $\times 440$.

giant nuclei appearing as though they have been formed by fusion of 2 to 3 nuclei (Fig. 3 ). In both types the cytoplasm contained numerous vacuoles of various sizes, which were identified as lipid droplets with Oil red O staining (Fig. 4). Besides the tumor cells, well differentiated, signet-ring shaped typical mature fat cells were diffusely distributed throughout the tumor. Stromal collagen fibers varied in their degrees of development according to the location inside the tumor

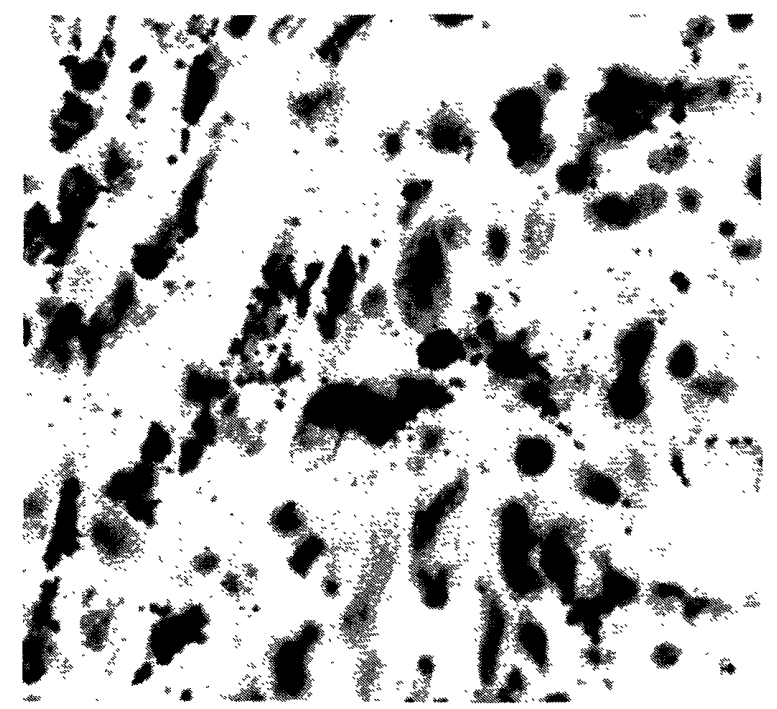

Fig. 4. Lipid droplets of various sizes in the cytoplasm of the tumor cells in the omentum. Oil red $\mathrm{O}$ staining, $\times 500$.

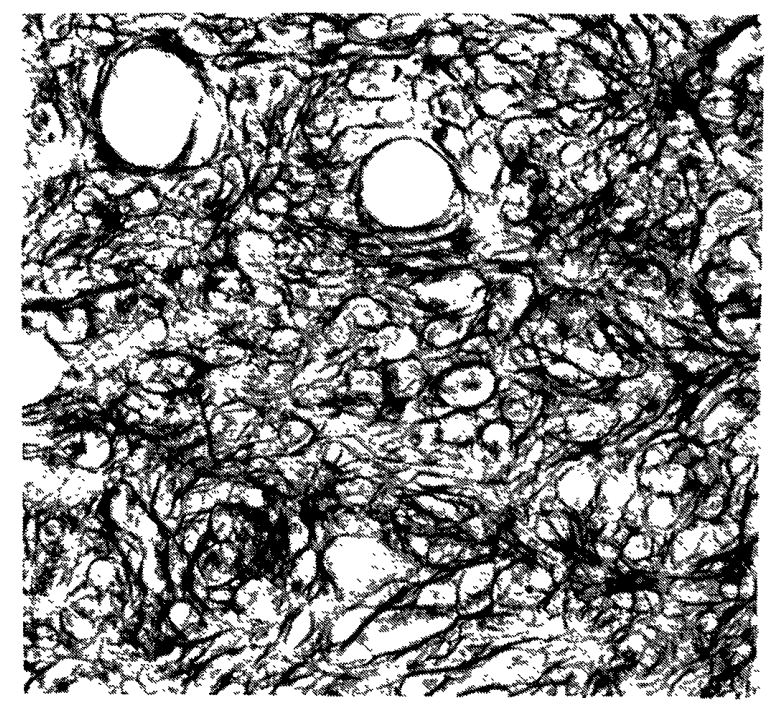

Fig. 5. Fine argentaffin fibrils encircling individual tumor cells and separating them from each other in the tumor found in the omentum. Silver impregnation, $\times 300$.

tissue. The azan staining and silver impregnation revealed proliferation of interstitial collagen fibers and argentaffin fibrils. Throughout the tumor tissue, fine argentaffin fibrils encircled individual tumor cells and separated them from each other (Fig. 5).

Ultrastructurally, the round cells had irregularly outlined nuclei and deeply invaginated nuclear membranes with dilatated perinuclear cisternae. Small round mitochondria and 


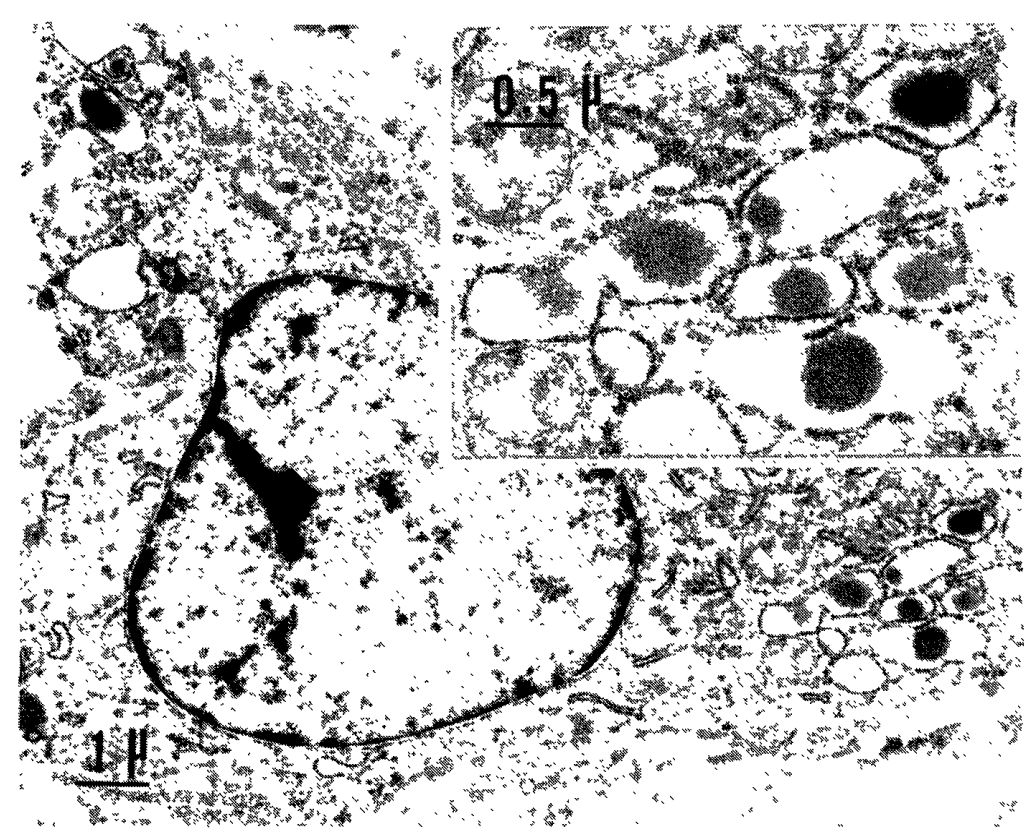

Fig. 6. A round tumor cell in the omentum. Electron dense round or oval amorphous materials in the dilatated cistern of the rough endoplasmic reticula. $\times 6,270$.

Inset: High power view of amorphous materials. $\times 13,860$.

rough endoplasmic reticula with dilatated cisternae were sparsely distributed in their cytoplasm. Some round cells contained electron dense round or oval amorphous material in the dilatated cistern of the rough endoplasmic reticulum (Fig. 6). This material was suspected to be lipid being synthesized. Some other round cells had various numbers of lipid droplets accompanied by no limited membrane around them in the cytoplasmic matrix (Fig. 7). The spindle cells had scanty cytoplasm with poor organellae and nuclei with marginated chromatin. Their cytoplasm contained large lipid droplets having no limited membrane around them. These morphological features of the tumor cells, especially various stages of lipid granule formation, had many points in common with those of lipoblasts in various stages of differentiation. These findings strongly suggest that the tumor derived originally from the lipoblast.

The tumor cells in the spleen and liver in the present case showed the same morphological features as the ones in the omentum and mesentery.

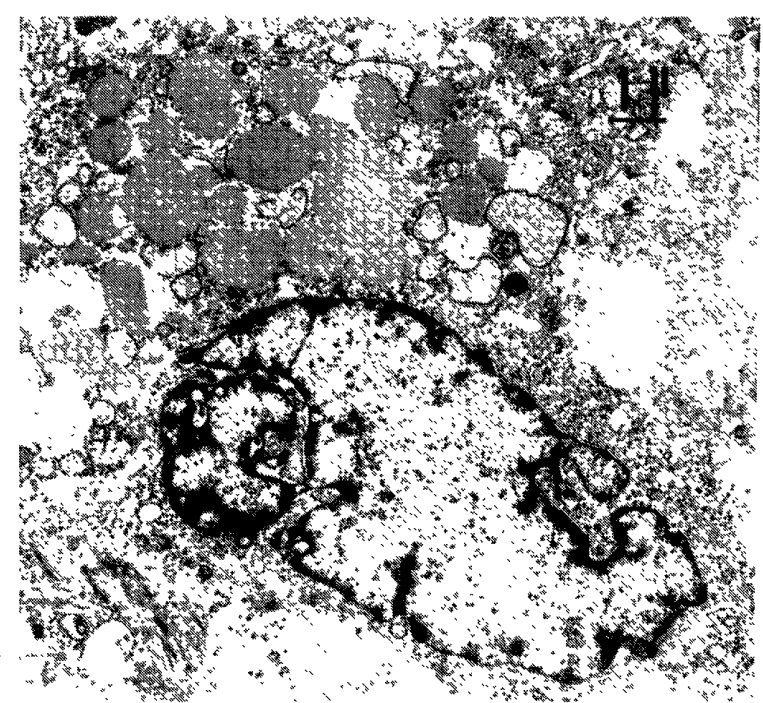

Fig. 7. A round tumor cell in the metastatic focus in the liver. Deeply invaginated nuclear membrane and lipid droplets without limited membrane in the cytoplasm. $\times 4,940$.

The tumor was diagnosed as pleomorphic liposarcoma on the basis of the following findings; (1) the tumor consisted of various cells representing features of lipoblasts in different developmental stages [1]; (2) the tumor cells exhibited marked atypia [10]; and (3) metastasis was observed in the spleen and 
liver.

In the diagnosis of liposarcoma, it is most important to differentiate them from malignant fibrous histiocytoma (MFH) [9]. Definitive diagnosis also requires demonstrating that lipoblast-like cells are a major constituent of the tumor $[2,8,9,10]$. Although both liposarcoma and xanthoma cells of MFH contain many lipid droplets in the cytoplasm [3, 7], those in the former are synthesized in the cytoplasm of the tumor cells [11], whereas those in the latter are phagocytosed and, therefore, have the limited membrane of phagosomes [8]. Also xanthoma cells have many lysosomal granules [3]. In silver impregnated sections, argentaffin fibrils found in liposarcoma encircle individual tumor cells, but the fibrils in MFH surround a cluster of tumor cells [8,9]. Based on these features, the present tumor was clearly differentiated from MFH.

\section{REFERENCES}

1. Carneiro, J., Contopoulos, A. N., and Junqueira, L. C. 1980. Adipose tissue, pp. 103-108. In:
Basic Histology, Maruzen, Tokyo.

2. Enjoji, M. 1982. Tr. Soc. Pathol. Jpn. 71: 51-88 (in Japanese).

3. Fujimaki, Y., Sugiyama, M., and Isoda, M. 1985. Jpn. J. Vet. Sci. 47: 147-150.

4. Goodman. D. G., Ward, J. M., Squire, R. A., Chu, K. C., and Linhart, M. S. 1979. Toxicol. Appl. Pharmacol. 48: 237-248.

5. Goodman, D. G., Ward, J. M., Squire, R. A., Paxton, M. B., Reichardt, W. D., Chu, K. C., and Linhart, M. S. 1980. Toxicol. Appl. Pharmacol. 55: 433-447.

6. Jacobs, B. B., and Huseby, R. A. 1967. J. Nat. Cancer Inst. 39: 303-309.

7. Minase, T. 1982. Tumors of connective tissue. pp. 42-49. In: Electron Microscopy of Tumors (Onoe, T. ed.), Nanzando, Tokyo (in Japanese).

8. Minase, T. 1982. Tumors of addipose tissue. pp. 61-68. In: Electron Microscopy of Tumors (Onoe, T. ed.), Nanzando, Tokyo (in Japanese).

9. Shimoda, T., Yamashita, H., Furusato, M., Kirino, Y., Ishikawa, E., Miyagawa, A., and Ubayama, Y. 1980. Acta. Pathol. Jpn: 30: 779-797.

10. Tsutsui, A. 1981. Soft tissue. pp. 11-32-11-45. In: Saishin Byouri Soshikigaku (Takeuchi, T., Ide, G., Kajikawa, K., Ogawa, K., Tsuchiyama, H., and Oonishi, Y. eds.), Rikogakusha, Tokyo (in Japanese).

11. Usuku, G., Iyama, K., and Ohzono, K. 1977. Igaku no ayumi 101: 238-245 (in Japanese).

\section{要 約}

老齢ラットに認められた多形性脂肪肉腫の一例(短報)：湊 良雄・高田 博・山中 久・小嶋明廣・和田 功 ・武下政一・岡庭 梓(田辺製薬株式会社安全性研究所) 一68 週龄のラット1例の大網および腸間膜に認めら れた多形性脂肪肉腫を病理組織学的に検討した。腫瘍は明調で大きな核と豊富な細胞質をもつ円形の細胞と暗調 で長楕円形の核をもつ紡錘形の細胞とから構成されていた。円形の細胞の拡張した粗面小胞体腔に脂肪合成の像 を認め，加えて円形および紡錘形の細胞の基質に限界膜をもたない大小様々の脂肪滴を認めた。以上の所見から 本腫瘍は多形性脂肪肉腫と診断された。 